\title{
KNOWLEDGE LEVEL OF AGRICULTURAL EMPLOYEES IN DUHOK DIRECTORATE ON INTEGRATED PEST MANAGEMENT
}

\author{
Hashim S. Murad \\ Dept. of Agricultural Extension \& Rural Development. College of Agricultural \\ engineering sciences, Duhok Univ.-Iraq \\ Email: Hashim.saeed@uod.ac
}

\begin{abstract}
The research aimed to identify the knowledge levels of the Duhok Agriculture employees on integrated Pest Management (IPM) fields. The correlation between the degree of employee knowledge and some independent variables identified. And to identify some personal and functional characteristics of the researchers consisted of two parts. The first part which contained the independent variables of the respondents and the second part included a test the level of knowledge of agricultural employees in the field of IPM including 38 items distributed over the 6 parts: 1. General principles 2. Control by agricultural methods 3. Physical control 4. Biological control. 5. Legislative control 6. Chemical control.

Data were collected through a personal interview with simple random samples of agricultural employees, representing $25 \%$ of the total of 52 respondents. The results showed that the degree of knowledge of Duhok agriculture employees in the field of integrated management in general was moderate and tends to high. Moreover, employees' knowledge in the field of biological control and their lack of experience with regard to biological enemies, predators and parasites was low. On the other hand, there were a significant correlation between the degree of knowledge of the respondents and each of the independent variables, (the number of family members, specialization, education level, and previous training). On the other hand, there was no correlation with other variables (Age, gender, work location, upbringing, number years of agricultural service, years of preventive agricultural service, Job title, and Information sources in the field of integrated pest management). The researcher recommended that the necessity of paying attention to the topic of IPM through expanding the scope of seminars and extension to increase the knowledge and information of agricultural employees, and work to prepare and implement the intensive and specialized training programs carried by the Ministry of Agriculture in the region.
\end{abstract}

Keywords: knowledge level, IPM, Duhok

Received: 26/1/2020, Accepted: 21/4/2020 


\section{INTRODUCTION}

Agriculture is one of the main sources of the national economy for many countries. Furthermore, it is the major exporting income for most of the population. Therefore, it is necessary to work on achieving agricultural development in order to reach the desired comprehensive development (Hassanein, 2000). Modern agricultural technologies are an essential means to increase agricultural production (Al-Taie, 2004). The increasing population growth in the world will lead to facing many challenges during the next decades. The main significant challenge is providing quantitative and qualitative food, which leads to food security.

Various pests (insects, diseases and bushes) have been affecting and causing losses in production before and after the harvest. This is impossible without effective prevention programs for food production (Al-Rubaie, 2006). Reducing these losses, man uses chemical pesticides as well as increases the food to meet the increasing population needs (Waheeb, 2011).

However, the excessive and indiscriminate uses of these chemical pesticides led to initiate many problems and the most obvious feature is the pesticide resistance appearance to many agricultural pests, which led to the complication of control operations. On same way, increase number of spraying times and doses led to cause environmental pollution as well as killing many beneficial natural enemies (Bashir, 2010).

According to Youssef and Mohamed (2004). The problem of pesticide residues poses a tremendous challenge in its presence in agricultural products. Survey studies on vegetable crops indicate that (50\%) of the samples were found the residual effect of the pesticide more than the permissible limit which is estimated at $(1 \mathrm{mg} / \mathrm{kg})$ Ali and Bayan (2014). In addition to the deterioration of the ratio of elements food. This is because of overuse of fertilizers and chemical pesticides. Clean agriculture needed to limit the use of pesticides and chemical fertilizers, which mainly based on IPM, organic and bio-fertilizers uses. IPM defined as an approach to pest management based on farms' use of all physical, natural and cultural methods economically and environmentally safe and effective in pest control. This allows using of minimum agricultural pesticides, and these methods include a mixture of biological control, soil management, use of resistant varieties, and agricultural proper practices.

Similarly, Racliffe et al (2009) defines it as a method of protecting the environment and making it a healthy environment through the use of natural predators and resistant plants and reducing dependence on harmful chemical pesticides. Cuyno et al, (2001), outlines the benefits of using IPM as follows:

1- Reducing harm to human health and the environment

2- It considered a preventive measure to reduce the amount of pesticides used in the process of pest control and reduce the cost.

3- It is more effective and less expensive than using pesticides. 
4- It helps in overcoming the risks which is resulting from storing pesticides

Recently, the world paid attention to designing integrated pest management programs using such a different manners. For example, encouraging the mass production of natural enemy, insect traps containing a sexual attractiveness, cultivating varieties resistant to diseases and insects, land service, and other agricultural mechanical and biological processes that reduce the incidence of agricultural pests. (Ammar, 2002).

As IPM includes many factors and interrelationships, thus there is a significant need for an experienced cadre who works as a team to accomplish its difficult role in developing its strategies that depend on dealing between technologies and specialties. Therefore, teams are required that include specialists in crops, horticulture, plant diseases, insects, bushes and other agricultural specialties to provide basic information to support and operate integrated pest management programs (Glass, 1992). Given the importance of the roles of these agricultural employees in developing agriculture and achieving sustainable agricultural and rural development (Shideed and Mohammad, 2006), it is necessary to know the level of their knowledge in this way, (El-Sayed, 2005).

Based on the foregoing and in view of the importance and modernity of the topic, this research came to try to answer the following questions:

1. What is the level of knowledge of Duhok agriculture employees, in each axis of items in the field of IPM in general?

2. What is the relationship between the degree of knowledge of agricultural employees in the Directorate of Duhok Agriculture in the field of IPM and each of the independent variables involved in the research?

\section{Objectives}

1. To identify some personal and functional characteristics agricultural employees in Duhok Governorate.

2. To identify the knowledge level of agricultural employees in Duhok Governorate in the field of IPM in general.

3. To identify the knowledge level of agricultural employees in the Duhok governorate in each domain and a paragraph of the field of integrated pest management.

4. To determine the correlation between the degree of employee knowledge in the field of integrated pest management and some personal and functional characteristics agricultural employees in Duhok Governorate.

\section{Research Hypotheses}

There is no significant between the degree of employee knowledge in the field of integrated pest management and some personal and functional characteristics of agricultural employees in Duhok Governorate.

\section{Procedural Definitions}


Knowledge level of agricultural employees in Duhok Governorate in the field of IPM: It means the degree of knowledge of employees in Duhok in the field of IPM expressed in numerical values.

Agricultural employees: The agricultural employees who work in the Directorate of Agricultural Duhok. They have higher certificate in agriculture, agricultural institutes and agricultural colleges in various agricultural specialties.

IPM: It is the consistency and complementarity of various preventive, chemical, and non-chemical control methods (general principles, agricultural methods control, physical control, biological control, legislative control, chemical control and reproductive inhibitors) in a system that aims to reduce the number of pests. Moreover, they do not it causes economic damage while maintaining the integrity of the environment from any harmful changes therein.

\section{MATERIALS AND METHODS}

The research community consisted of all agricultural employees who work in the Directorate of Duhok Agriculture / Duhok Governorate, accounting 208. The simple random (sample 52 employees) was selected, representing 25\%. For the purpose of collecting data for the research. A questionnaire was prepared to collect data from agricultural employees, which included two parts: the first part consisted of personal and functional variables for agricultural employees in the Directorate of Duhok Agriculture.

The second part of the Questionnaires a test to measure the level of knowledge, which included six knowledge axes which are: general principles 5 items and control by agricultural methods 7 items and physical and mechanical control 7 items and biological control 5 items and legislative control 5 items and chemical control and inhibitory materials for reproduction 9 items.

The independent variables represented by gender was (male $=1$, female $=2$ ). Work location was sub-district center $=1$, district center $=2$, governorate center $=3$ and upbringing was (rural $=1$, urban $=2$. The levels of education were tabulated and coded as Agriculture $=1$, an agricultural institute $=2$, the college of agriculture $=3$, a higher diploma $=4$, a master's, 5 (academic specialization) specializing in plant protection $=1$ and other majors $=2$. Participating in training courses in the field of IPM (I did not participate $=1$ and participant in the course $=2$ ). The job title (agricultural engineer (1) senior agricultural engineer (2) chief agricultural engineer older (3) agricultural extension worker (4) senior agricultural extension worker (5).

While the source of agricultural information use a three-scale includes 10 items and a component of the following levels: (always, sometimes and do not touch upon was giving weights: 3.2.1) respectively. As for the independent quantitative variables such as age, the number of family members, years of service in the agricultural and preventive sector that were classified according to the degrees obtained by each researcher, while the second part of the Questionnaire consists of a test to measure the level of knowledge of Duhok agricultural employees in the field of IPM which included 45 items (for primary testing). 
The content of the questionnaire was verified and approved during of presented to some specialists and professors in the field of the Plant Protection Department / College of Agriculture and Forestry / University of Mosul, and the College of Agricultural Engineering Sciences / University of Duhok to evaluate the questionnaire phrases in the process of measuring the content of the subject.

In addition, the reliability of the terminal comparisons was used by applying the test to a simple random sample consisting of 15 agricultural employees (excluded from the final research sample). The test was corrected and then the test scores were arranged in descending order and were divided into two groups; an upper group and a lower group. The arithmetic averages for both groups were compared and the averages were calculated by the $\mathrm{T}$ test and the calculated value of $\mathrm{t}$ was 11.68 degrees which is greater than the tabular value of $\mathrm{t}$ at Level $1 \%$. This indicates that the test has the ability to distinguish between both groups with a high cognitive level and a low cognitive level, meaning that the test is valid (Abdel Hafeez and Bahi, 2000).

Likewise, the coefficient of the difficulty of the items was found, as the very easy and very difficult items. Which occurred outside the range $0.20-0.80$, were deleted. Therefore, the number of test items in their final Questionnaires reached 38 test items, all of which were of multiple choice. The number of alternatives to answer each paragraph 4 was chosen one of them was by the respondent, and one grade was given to the employee who knows the answer to the paragraph correctly and zero for the employee who does not know the correct answer to the paragraph.

After completing the Questionnaires in its final form, the research' data was collected and analyzed using the SPSS program to extracting percentages and standard and mean deviation (Jawdah, 2009).

\section{RESULTS AND DISCUSSION}

First: Identify some personal and functional characteristics of agricultural employees in Duhok Governorate.

Table (1) illustrates the distribution of the respondents according to the following personal and functional characteristics which depend on: the age, whereas respondents were divided into three categories. The table shows an increase in the percentages of the age group (24-37 years) (38-51 years) with the same percentage which reached $46.2 \%$ for each and this ratio represents the highest. While the lowest was $7.6 \%$ in the age group (52-65 years). Regarding to gender, the respondents were divided into two categories. The male category formed the highest percentage which reached $61.5 \%$ than female category which was $38.5 \%$. Regarding the work location, the respondents were divided into three categories, the high percentage of respondents was 44 in the governorate center which reached $84.6 \%$, while the lowest percentage for the district and district centers reached $5.8 \%$ and $9.6 \%$ respectively. As for the upbringing, the respondents were divided into two categories, the percentage of urban group formed the higher which reached $75 \%$ than rural category that reached $35 \%$. While the variable of number of family members, the respondents were divided into three groups. It can 
be seen an increase in the percentage of individuals (5-7) which reached 50\%, while the group ( 8 people or more) was $15.4 \%$. Which lowest percentage.

In addition, the respondents were divided according to their specialization into two categories, the percentage of those who work in plant protection reached $21.2 \%$. Which is lower than other majors (78.8\%). As for the number of years of service to farmers, respondents were divided into three categories, the highest percentage was $71.1 \%$ for the category (1-13 years), while the lowest percentage was $3.8 \%$ for the category (27 years or more). Moreover, the respondents were divided into three categories depends on the number of years of preventive service. It was found that the highest percentage reached $90.4 \%$ for the category (0-12 years), while the lowest rate was $3.8 \%$ for the 26-year and more. According education level, the respondents were divided into five categories: $65.4 \%$ of holders of Bachelor's Degree degrees which was the highest, baccalaurean and master's degrees appeared at the same percentage $9.6 \%$, the diploma certificate was $11.5 \%$ and the holders of higher diploma was $3.8 \%$, which is the lowest percentage of the total of the research sample. For the previous training courses in the field of IPM, the percentage of participants in the research sample who were not trainees and trainees which reached the same percentage which is $50 \%$. The participants were divided into five categories according to their job titles as follows. It was found that the highest proportion of the of senior agricultural engineer was $26.9 \%$, the chief agricultural engineer was $23.1 \%$, the agricultural extension worker $21.2 \%$, the senior agricultural extension worker $15.4 \%$, while the lowest level position of agricultural engineers was $13.5 \%$. Finally, the respondents were divided according to the sources of their obtaining information in the field of integrated pest management into 3 groups. The few category (10-16 sources) reached 48.15 which is the highest percentage, the intermediate group (17-23 sources) increased by $44.2 \%$ and the lowest proportion was (7.7\%) for the high source's category (24-30 sources) out of the total sample of the research.

Second: Estimating the knowledge level of agricultural employees in Duhok Governorate in the field of IPM in general. The respondents were distributed according to their knowledge level, using the method of range and length of the group into three categories. The results showed that (5) respondents exemplified (9.6\%) and their knowledge level was low. The level of knowledge was moderate was $(73.1 \%)$ for 38 respondents. The third group had the highest level of knowledge (17.3\%) for (9) subjects represented of the number of respondents as shown in table (2).

Third: Determining the knowledge level of agricultural employees in the Duhok governorate in each domain and a paragraph of the field of integrated pest management. 
Mesopotamia J. of Agric.

Vol. (48) No. (2) 2020
ISSN: 2224 - 9796 (Online)

ISSN: 1815 - 316 X (Print)
مجلة زر اعة الر افدين

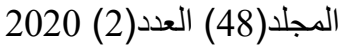

Table (1): Distribution of respondents according to personal and functional characteristics.

\begin{tabular}{|c|c|c|c|c|}
\hline No. & Variables & Categories & Number & Percentage \\
\hline \multirow{3}{*}{1} & \multirow{3}{*}{ Age } & $24-37$ years & 24 & 46.2 \\
\hline & & $38-51$ years & 24 & 46.2 \\
\hline & & $52-65$ years & 4 & 7.6 \\
\hline \multirow{2}{*}{2} & \multirow{2}{*}{ Gender } & Male & 32 & 61.5 \\
\hline & & Female & 20 & 38.5 \\
\hline \multirow{3}{*}{3} & \multirow{3}{*}{ Place of work } & Center of sub-district & 5 & 9.6 \\
\hline & & District Center & 3 & 5.8 \\
\hline & & Governorate Center & 44 & 84.6 \\
\hline \multirow{2}{*}{4} & \multirow{2}{*}{ Up bringing } & Rural & 13 & 25 \\
\hline & & Urban & 39 & 75 \\
\hline \multirow{3}{*}{5} & \multirow{3}{*}{ The number of family members } & $2-4$ persons & 18 & 34.6 \\
\hline & & 5-7 persons & 26 & 50 \\
\hline & & 8 persons or more & 8 & 15.4 \\
\hline \multirow{2}{*}{6} & \multirow{2}{*}{ Specialization } & Plant Protection & 11 & 21.2 \\
\hline & & Others Specialization & 41 & 78.8 \\
\hline \multirow{3}{*}{7} & \multirow{3}{*}{$\begin{array}{c}\text { Number of years of agricultural } \\
\text { service }\end{array}$} & $1-13$ years & 37 & 71.1 \\
\hline & & $14-26$ years & 12 & 23.1 \\
\hline & & 27 years and over & 2 & 3,8 \\
\hline \multirow{3}{*}{8} & \multirow{3}{*}{$\begin{array}{l}\text { Years of preventive agricultural } \\
\text { service }\end{array}$} & $0-12$ years & 47 & 90.4 \\
\hline & & $13-25$ years & 3 & 5.8 \\
\hline & & 26 years and over & 2 & 3.8 \\
\hline \multirow{5}{*}{9} & \multirow{5}{*}{ Education Level } & Agricultural Primary & 5 & 9.6 \\
\hline & & Agricultural Institute & 6 & 11.5 \\
\hline & & College of Agriculture & 34 & 65.4 \\
\hline & & Higher diploma & 2 & 3.8 \\
\hline & & Master & 5 & 9.6 \\
\hline \multirow{2}{*}{10} & \multirow{2}{*}{ Previous Training } & Yes & 26 & 50 \\
\hline & & No & 26 & 50 \\
\hline \multirow{5}{*}{11} & \multirow{5}{*}{ Job title } & Agricultural engineer & 7 & 13.5 \\
\hline & & $\begin{array}{c}\text { Senior agricultural } \\
\text { engineer }\end{array}$ & 14 & 26.9 \\
\hline & & $\begin{array}{l}\text { Senior Agricultural } \\
\text { Engineers Chief }\end{array}$ & 12 & 23.1 \\
\hline & & Agricultural extension & 11 & 21.2 \\
\hline & & $\begin{array}{c}\text { Senior agricultural } \\
\text { extension }\end{array}$ & 8 & 15.4 \\
\hline \multirow{3}{*}{12} & \multirow{3}{*}{$\begin{array}{l}\text { Sources of information in the field } \\
\text { of integrated pest management }\end{array}$} & 10-16 Source & 25 & 48.1 \\
\hline & & 17-23 Source & 23 & 44.2 \\
\hline & & 24-30 Source & 4 & 7.7 \\
\hline
\end{tabular}


Table (2): Distribution of respondents according to the level of knowledge in the field of integrated pest management in general

\begin{tabular}{|l|c|c|}
\hline \multicolumn{1}{|c|}{ Categories } & Number & Percentage \\
\hline Low 0-12 degrees & 5 & 9.6 \\
\hline Moderate 13-25 degrees & 38 & 73.1 \\
\hline High 26-38 degrees & 9 & 17.3 \\
\hline Total & 52 & $100 \%$ \\
\hline
\end{tabular}

The lowest value is 0 , the highest value is 38 , the mean is 18.193 , and the standard deviation is 6.210 .

Table (3) indicates that the axis of chemical control and inhibitory materials for reproduction ranked first among the themes of IPM with a moderate score of (4.519). This refers that the majority of agricultural employees possess high knowledge in this field as a result of the use of chemical control within the integrated management programs and the quality of the materials used therein.

Additionally, how to use of this material is safely and its effects on health and the environment for the majority of farmers' use of chemical pesticides. This made training programs directed for them in the use of chemical pesticides. Wide availability in most agricultural supply offices is found and easily of use.

Whereas the biological control axis occupied the last rank with an average arithmetic $(2,154)$ and this reflects the need of agricultural employees for training programs using biological control programs and how to use parasites and natural predators to control agricultural pests to reach the clean and safe agriculture as shown in Table (3).

It can be seen in Table (3) that the items that occupied the last grade in the fields of research are a paragraph (Knowledge of the benefits of applying IPM) in the field of general principles, a paragraph (Knowledge of the importance of planting dates as part of control process) and a paragraph (Knowledge regulating the use of chemical and organic fertilizers) In the field of agricultural methods control, a paragraph (Skills of using air vacuum to control the insects of the warehouse) in the field of physical and mechanical control, a paragraph (Skills required in rearing, releasing natural enemies to control agricultural pests) in the field of biological control, a paragraph (Knowledge of the considerations to consider in quarantine) in the field of legislative control, a paragraph (Knowledge of safe use of chemical pesticides), a paragraph (Knowledge of the type of toxicity caused by LC50) in the field of chemical control and inhibiting materials for reproduction and growth. This indicates that employees have lack of the knowledge and information in these items, the reason may be the lack of training courses in the field of plant protection.

Fourth: Determining the correlation between the degree of employee knowledge in the field of IPM and some personal and functional characteristics of Duhok agriculture employees. 
Mesopotamia J. of Agric.

Vol. (48) No. (2) 2020
ISSN: 2224 - 9796 (Online)

ISSN: 1815 - 316 X (Print)
مجلة زر اعة الر افدين

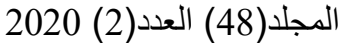

Table (3): Arranging test items according to the arithmetic mean for the level of knowledge of Duhok cultivation employees

\begin{tabular}{|c|c|c|}
\hline Areas and Items & Arithmetic mean & Rank \\
\hline General principles & 2.673 & 4 \\
\hline Knowledge of designing agricultural pest management programs & 0.750 & 1 \\
\hline Knowledge of estimating the infection levels of agricultural pests & 0.596 & 2 \\
\hline Knowledge of agricultural pest monitoring and predicting system & 0.519 & 3 \\
\hline Knowledge of determining the economic levels of agricultural pests & 0.462 & 4 \\
\hline Knowledge of the benefits of applying IPM & 0.346 & 5 \\
\hline Agricultural methods control & 3.365 & 2 \\
\hline Knowledge of the benefits of surface tillage & 0.731 & 1 \\
\hline Knowledge of the factors affecting plant resistance characteristics & 0.596 & 2 \\
\hline $\begin{array}{l}\text { Knowledge of the importance of plant debris removing to prevent agricultural } \\
\text { pests }\end{array}$ & 0.558 & 3 \\
\hline Knowledge of the use of plant varieties resistant to pests & 0.500 & 4 \\
\hline Knowledge of using integrated pest management for control & 0.442 & 5 \\
\hline Knowledge of the importance of planting dates as part of control process & 0.269 & 6.5 \\
\hline Knowledge regulating the use of chemical and organic fertilizers & 0.269 & 6.5 \\
\hline Physical and mechanical control & 2.905 & 3 \\
\hline Skills of using stick traps to control agricultural pests & 0.692 & 1 \\
\hline Manual skills in hand collecting of insect larvae in field & 0.538 & 2 \\
\hline Skills of using barriers to control agricultural pests & 0.481 & 3 \\
\hline Knowledge of using relative humidity in agricultural pest control & 0.425 & 4 \\
\hline Knowledge of temperature using to control warehouse pests & 0.308 & 5 \\
\hline Skills of using hot water to control some seed fungi & 0.288 & 6 \\
\hline Skills of using air vacuum to control the insects of the warehouse & 0.173 & 7 \\
\hline Biological control & 2.154 & 6 \\
\hline Knowledge of using biological control to control agricultural pests & 0.731 & 1 \\
\hline $\begin{array}{l}\text { Knowledge of the benefits of using natural enemies in agricultural pest } \\
\text { control }\end{array}$ & 0.577 & 2 \\
\hline $\begin{array}{l}\text { Knowledge of the types of parasitoids, predators and pathogens used in } \\
\text { biological control }\end{array}$ & 0.404 & 3 \\
\hline Knowledge of the most important procedures for introducing natural enemies & 0.269 & 4 \\
\hline $\begin{array}{l}\text { Skills required in rearing and releasing natural enemies to control agricultural } \\
\text { pests }\end{array}$ & 0.173 & 5 \\
\hline Legislative control & 2.577 & 5 \\
\hline Knowledge of the importance of agricultural quarantine & 0.827 & 1 \\
\hline Knowledge of agricultural quarantine methods & 0.577 & 2 \\
\hline Knowledge of agricultural quarantine laws in Iraq & 0.519 & 3 \\
\hline $\begin{array}{l}\text { Knowledge of the qualifications that must be met by workers in agricultural } \\
\text { quarantine }\end{array}$ & 0.481 & 4 \\
\hline Knowledge of the considerations to consider in quarantine & 0.173 & 5 \\
\hline Chemical control and reproductive inhibitors & 4.519 & 1 \\
\hline Skills required to use pheromone traps for pest control & 0.712 & 1 \\
\hline Knowledge of using plant extracts for agricultural pest control & 0.577 & 2 \\
\hline Knowledge of the type of toxicity causing LD50 & 0.558 & 3 \\
\hline Knowledge of using anti-nutritional materials for insect control & 0.538 & 4.5 \\
\hline $\begin{array}{l}\text { Knowledge of the effects of pesticide residues on human health and the } \\
\text { environment }\end{array}$ & 0.538 & 4.5 \\
\hline
\end{tabular}




\begin{tabular}{|l|c|c|}
\hline \multicolumn{1}{|c|}{ Areas and Items } & Arithmetic mean & Rank \\
\hline Knowledge of using agricultural pest repellants & 0.500 & 6 \\
\hline Knowledge of using (growth regulators) for insect control & 0.404 & 7 \\
\hline Knowledge of safe use of chemical pesticides & 0.346 & 8.5 \\
\hline Knowledge of the type of toxicity caused by LC50 & 0.346 & 8.5 \\
\hline
\end{tabular}

For the purpose of determining the correlation between the degree of knowledge and the following variables, the simple correlation coefficient of Pearson was used: age, number of family members, number of years of functional service, number of years of preventive agricultural service, information sources in the field of IPM. The results show that there was no significant correlation between the variables and the degree of Knowledge, with the exception of the variable number of years of agricultural service. This is may be due to cumulative experience as a result of work for many years, which makes the individual possesses a large knowledge storage as a result of learning by doing. This leads to generated high knowledge of how to use pesticides and how to avoid risks resulting from misuse. Consequently, it is reflected on their level of knowledge.

The Spearman correlation coefficient was also used between the degree of knowledge and each of the following variables: gender, work location, upbringing, specialization, academic achievement, previous training, and job title. The results show that there was no significant correlation between the degree of knowledge and each of the gender, upbringing, place work, job title. While the results showed a significant correlation between the degree of knowledge and each of the variable of specialization, academic achievement and previous training.

The reason may be that because the employees are more specialized in the field of plan protection and their higher educational achievement and have previous training experience in this field and, therefore, more their information and knowledge will increase in the field of IPM.

Based on the results of the research, we conclude the following:

1. The degree of knowledge of Duhok agriculture employees in general is moderate tend to high in the field of IPM. This is due to their acquisition of sufficient knowledge in this field through training programs, especially the half of the respondents received training and search for scientific information in this field.

2. The result shows the majority of the respondents were used to training programs, which positively reflected on their agricultural knowledge.

3. The low knowledge of Duhok agriculture employees in the field of bio-control and their limited experience with regard to vital enemies, predators and parasites. This is because the majority of the respondents are not specialized in plant protection, which affected their degree of knowledge of them in the field. 
Table (4): relationship shows the degree of knowledge in the field of integrated pest management for Duhok agriculture employees and between some personal and functional characteristics.

\begin{tabular}{|c|l|c|c|c|c|}
\hline $\begin{array}{c}\text { No } \\
\cdot\end{array}$ & \multicolumn{1}{|c|}{ Variables } & $\begin{array}{c}\text { Person } \\
\text { Correlation }\end{array}$ & $\begin{array}{c}\text { Spearman Rank } \\
\text { Correlation }\end{array}$ & $\begin{array}{c}\mathrm{T} \\
\text { value }\end{array}$ & $\begin{array}{c}\text { significant } \\
\text { level }\end{array}$ \\
\hline 1 & Age & 0.116 & & 0.826 & N.S \\
\hline 2 & Gender & & -0.046 & 0.326 & N.S \\
\hline 3 & Work location & & -0.144 & 1.029 & N.S \\
\hline 4 & Up bringing & 0.234 & & 1.368 & N.S \\
\hline 5 & Number of family members & & -0.476 & 3.827 & $* *$ \\
\hline 6 & Specialization & 0.180 & & 1.294 & N.S \\
\hline 7 & $\begin{array}{l}\text { Number years of agricultural } \\
\text { extension }\end{array}$ & -0.204 & & 1.473 & N.S \\
\hline 8 & $\begin{array}{l}\text { Years of preventive } \\
\text { agricultural extension }\end{array}$ & & -0.382 & 2.923 & $* *$ \\
\hline 9 & Education Level & 0.305 & 2.265 & $* *$ \\
\hline 10 & Previous training & 0.046 & 0.326 & N.S \\
\hline 11 & Job title & & 1.102 & N.S \\
\hline 12 & $\begin{array}{l}\text { Information sources in the } \\
\text { field of integrated pest } \\
\text { management }\end{array}$ & 0.154 & & & \\
\hline
\end{tabular}

*significant at $0.05 * *$ significant at 0.01

4. Insufficiency of knowledge of Duhok agriculture employees in the knowledge items (Knowledge of the benefits of applying (IPM) in the field of general principles, a paragraph (Knowledge of the importance of planting dates as part of control process), a paragraph (Knowledge regulating the use of chemical and organic fertilizers) in the field of agricultural methods control, a paragraph (Knowledge of the type of toxicity caused by LC50) in the field of physical and mechanical control, a paragraph (Skills required in rearing and releasing natural enemies to control agricultural pests) in the field of biological control, a paragraph (Knowledge of the considerations to consider in quarantine) In the field of legislative control, a paragraph (Knowledge of safe use of chemical pesticides), a paragraph (Knowledge of the type of toxicity caused by LC50) in the field of chemical control and materials that inhibit the reproduction and growth .

5. There are variables that have shown their relationship in the field of IPM, namely the number of family members, specialization, education level and previous training, while no correlation has emerged with the rest of the other variables. Accordingly, the researcher recommends the following:

a. Focusing on the importance of on-the-job training in the field of integrated pest management through the preparation and implementation of intensive and specialized training programs that fall under the responsibility of the Ministry of Agriculture. 
b. Forming committees from the Plant Protection Department in the College of Agriculture and the Ministry of Agriculture to carry out campaigns to uncover methods used in control of bushes and insects by farmers so that training programs are tailored to suit the reality of farmers and their needs.

c. The necessity of paying attention to the issue of integrated pest management by expanding the scope of seminars and guiding brochures on these topics. This leads to increase the knowledge and information of agricultural employees in this aspect and work to develop control programs.

d. Directing educational programs related to the integrated management of agricultural pests for biological control. Additionally, it should be paying attention to agricultural television programs that are particularly concerned with integrated management and setting a specific time to present those programs in free time of agricultural employees.

6. The necessity of taking into consideration the individual differences between agricultural employees when preparing their training courses in the field of IPM. Moreover, it should be emphasizing variables related to the training need, number of family members, specialization, academic achievement and participation in training courses in the field of IPM.

\title{
المستوى المعرفي للموظفين الزراعيين في محافظة دهوك في مجال الادارة المتكاملة للآفات الزراعية هاشم سعيد مراد \\ قسم الإرشاد الزراعي والتتمية الريفية / كلية علوم الهندسة الزراعية / جامعة دهوك/ العراق \\ Email: Hashim.saeed@uod.ac
}

\begin{abstract}
الخلاصة
استهذف البحث تقدير المستوى المعرفي لموظفي زراعة دهوك بكل محاور الادارة المتكاملة للآفات الزراعية وتم تحديد العلاقة الارتباطية بين درجة معرفة الموظفين وبعض العوامل المستقلة بالإضافة الى التعرف التافي على بعض الخصائص الثخصية والوظيفية للمبحوثين، ولانجاز هذا البحث اعدت استمارة استبيان في ضوء قراءة الادبيات ومعرفة اراء الخبراء المختصين وموافقتهم حيث تكونت من جزئين تضمن الجزء الاول منها على العوامل المستقلة الخاصة بالمبحوثين أما الجزء الثاني فقد تضمن اختبار لمستوى معارف الموظفين الزراعين في مجال الادارة المتكاملة للآفات المتكونة من 38 فقرة توزعت على 6 محاور هي: 1.المبادئ العامة 2.المكافحة بالطرائق الزراعية 3.المكافحة الفيزيائية 4.المكافحة الحيوية 5.المكافحة التشريعية 6 .المكافحة الكيميائية. جمعت البيانات بطريقة المقابلة الثخصية مع عينة عشوائية بسيطة من الموظفين الزراعيين بنسبة 25\% وبواقع 52 مبحوثاً.

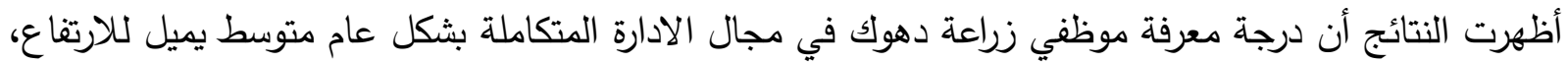
وانخفاض معرفتهم بمجال الدكافحة الحيوية وقلة خبرتهم بما يتعلق بالأعداء الحيوية والمفترسات والطفيليات.
\end{abstract}


كما واظهرت النتائج وجود علاقة ارتباطيه معنوية بين درجة معرفة المبحوثين وكل من المتغيرات المستقلة وهي (عدد افراد الاسرة والتخصص والتحصيل الدراسي والتدريب السابق). في حين لم تظهر اية علاقة ارتباط مع بقية العوامل الاخرى. واوصى الباحث بضرورة الاهتمام بموضوع الإدارة المتكاملة للآفات الزراعية عن طريق توسيع نطاق الندوات والنشرات الإرشادية الخاصة بها لزيادة معارف ومعلومات الموظفين الزراعيين في هذا الجانب والعمل على تطوير برامج المكافحة من خلال إعداد وتتفيذ برامج تدريبية مكثفة ومتخصصة تعنى بمسؤوليتها وزارة الزراعة في الاقليم. الكلمات الدالة: المستوى المعرفي، المكافحة المتكاملة، دهوك. تاريخ تسلم البحث: 2020/01/26 ، وقبوله : 2020/4 21 2015،

\section{REFERENCES}

Abdel Hafeez, I. M. and Bahi, M. H. (2000). Scientific Research Methods and Statistical Analysis in the Educational, Psychological and Sports Fields, the Book Center for Publishing, Egypt.

Ammar, E. A. (2002), Knowledge Level Of Farmers In The Field Of Integrated Weed Control In Some Villages Of Kafr El-Sheikh Governorate, Alexandria Journal of Scientific Exchange, Volume (23), No, (2).

Al-Rubaie, H. F. (2006), Integrated pest control systems, justifications and methods, Iraqi agriculture journal, Vol. (11) No. (3)

Al-Taie, H. Kh. (2004). The Productive Gap in the Application of New Agricultural Technologies is a Loss for the Agricultural Producer and Society. Iraqi Journal of Agriculture, Vol. 9, No. 2.

Ali, S. F. And Bayan A. J. R. (2014), Training Needs of Agricultural Employees in the Province of Kirkuk in The Field of Integrated Management of Agricultural Pests and Their Relationship to Some Factors, University of Kirkuk Journal of Agricultural Sciences, Vol. (5), No. (1).

Bashir, A. (2010). The role of attractive sex pheromones in biological control in organic agriculture, journal of agriculture and water in the Arab world, Vol. (3) No. (26)

Cuyno, L. C. Norton, G. W. \& Rola, A. (2001). Economic analysis of environmental benefits of integrated pest management: a Philippine case study. Agricultural economics, 25 (2-3), 227-233.

Hassanein, M. A. (2000) The Role of Agricultural Extension in Spreading and Adopting Integrated Control Practices Among Cotton Farmers in Gharbia Governorate, Ph.D. Thesis, unpublished, faculty of agriculture, Cairo university.

Glass, E. (1992) Integrated Pest Management, Presentation of Principles, Capabilities, Requirements, and Implementation. Translated by Dr. Jalil Abu Al-Hab, General Cultural Affairs House. Baghdad, Iraq.

Jawdah, M. (2009). Basic Statistical Analysis Using SPSS, 12 Wael Publishing House. 
El-Sayed, T. M. (2005). Training Needs for Field School Mentors for Integrated Pest Management, Unpublished Master Thesis, Institute of Environmental Studies And Research, Ain-Shams University. Egypt.

Waheeb, J. F. (2011). Chemical Pesticides are Important and Control Their Use. Iraqi Agriculture Journal, Vol. (15), No. (3)

Youssef, E. A. and Mohamed El- Sh, El. (2004) Determinants of Vital Fertilizer Spreading In Some Villages In Kafr El-Sheikh Governorate, Journal. Mansoura University for Agricultural Sciences, Egypt, Vol. (29), No. (6)

Shideed, K. H. and Mohammad El. (2006). Adoption and Impact Assessment of Improved Technologies Crop and Livestock Production Systems in the Dry Areas, ICARDA IFAD.

Racliffe, E. B. and William D. H. and Rafael E. C. (2009). Integrated Pest Management, Amazon, University of Minnesota, U.S.A. 